\title{
Az informatikai gondolkodás (computational thinking) fogalmi keretei
}

\author{
Csernai Zoltán \\ Eszterházy Károly Egyetem \\ csernai.zoltan@uni-eszterhazy.hu
}

\section{The conceptual framework of computational thinking}

The Fourth Industrial Revolution radically changes the system of abilities and skills expected of the citizen of the 21st century. As priorities are shifted from knowledge to competence heretofore unseen demands emerge at the labour market. One of the current priorities is the improvement of STEM competences, that is, the acquisition of knowledge and skills related to (S)cience, (T)echnology, (E)ngineering, and (M) athematics via interdisciplinary and transversal instruction schemes.

According to experts the demand related to STEM competences and skills is expected to increase. Analysts forecast a 3\% overall growth in employment in the EU until 2020, and this figure could reach up to 9\% in STEM-impacted professions (Szegedi, 2014). Simultaneously computational thinking (Wing, 2008) is gaining increasing popularity as an umbrella term for the aforementioned four areas.

Subscribing to a deductive approach utilizing a specifically elaborated criteria system, I explore various interpretations of the given concept in the international community. Furthermore, I will analyse the respective manifestations in the DigComp 2.1. framework system (Carretero, Vuorikari \& Punie, 2017) approved by the European Union.

This effort is a preliminary stage for further inquiry into the domestic situation especially the examination of the documentation of specific education management initiatives [MDOS, 2016 (Digital Education Strategy of Hungary); NAT (National Curriculum) 2018].

In the next phase of my research I will explore computation thinking-related attitudes in teacher training by the combined paradigm method (Sántha, 2014) My research tools include a self-developed measurement device along with questionnaires and interviews as well.

Keywords: Computational thinking, DigComp 2.1

\section{Problémafelvetés}

A 4. ipari forradalom hatására megváltozik a 21. századi állampolgártól elvárt képességek rendszere, a tudásról egyre inkább a kompetenciákra helyezödik a hangsúly, a munkaerőpiacokon a korábbitól eltérő elvárásokjelennek meg. Napjaink egyik fő irányvonala a STEM területek fejlesztése, amelya (S) természettudományos, a (T) technológiai, a (E) mérnöki tudományokat és a $(M)$ matematikát helyezi elötérbe, annak interdiszciplináris és transzverzális oktatása révén. 
A STEM területekhez kapcsolódó képességek iránti kereslet ugyanis növekedni fog, az elemzök az 2020-ig az EU-ban átlagosan 3\%-os foglalkoztatottsági növekedés várnak, a STEM és a társult szakmákon belül ez az érték $9 \%$ lehet. ${ }^{1}$

A digitális gazdaság és társadalom fejlettségét mérő DESI-index (Digital Economy and Society Index -DESI) azt vizsgálja, hogy mennyire állnak készen az Európai Unió tagállamai a digitális átállásra.

ADESl egyik pillére (2. Humán töke) azt méri, hogy az egyénnek milyen képességekre van szüksége a digitális társadalomban való boldoguláshoz, amelyhez az alábbi indikátorok szükségesek (1. ábra):

Internetfelhasználók

Alapvető digitális készségek

IKT-szakemberek

STEM diplomások

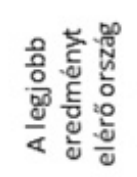

DESI 2018 Relatív teljesítmény dimenziónként

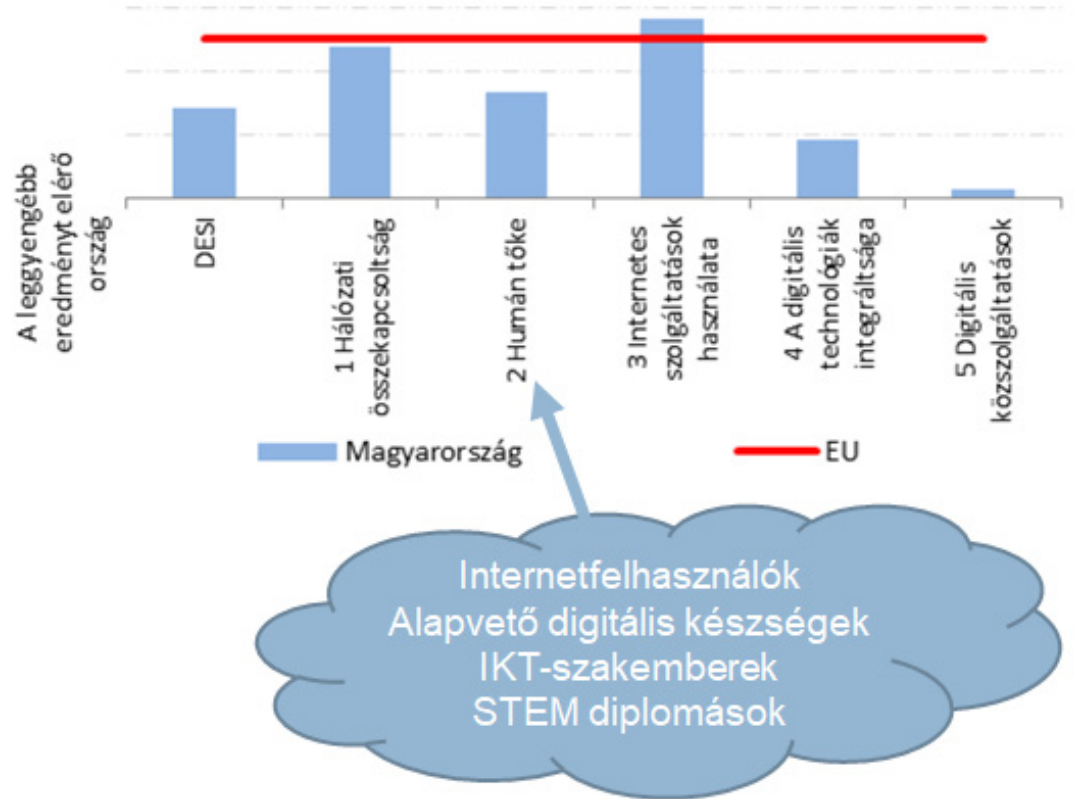

1. ábra: A digitális gazdaság és társadalom fejlettségét mérő mutató (DESI), 2018, Magyarországról szóló országjelentés

(Forrás: Digital Economy and Society Index 2018 - Magyarország. URL: http://europa.eu/rapid/press-release_MEMO-18-3737_en.htm)

1 Szegedi Eszter. "Miért került világszerte fókuszba a STEM területek oktatása?" pp. 9-14., 2014. http://tka.hu/docs/palyazatok/belestem.pdf 
Az oktatás digitális átállása ugyan elkezdődött, azonban nincsen egységes fogalomkészlete. Bizonyos esetekben, tévesen szinonimaként utalnak az emberek az informatikai gondolkodásra, a digitális kompetenciára és az algoritmikus gondolkodásra.

Kutatásom célja, hogy deduktiv módon megvizsgáljam, hogy nemzetközi szinten hogyan értelmezik e fogalmat, és egy kidolgozott szempontrendszer alapján elemezzem az Európai Unió által elfogadott ${ }^{2}$ keretrendszerben való megjelenését.

A Computational Thinking fogalmának értelmezései

A Computational Thinking (CT) fogalmát a nemzetközi szakirodalomban nem egységesen értelmezik, többnyire a fogalom egyes részterületeiben rejlö fejlesztési lehetőségekre fókuszálnak. Kutatásom során a CT fogalmi fejlődésének legfontosabb állomásait mutatom be. (2. ábra)

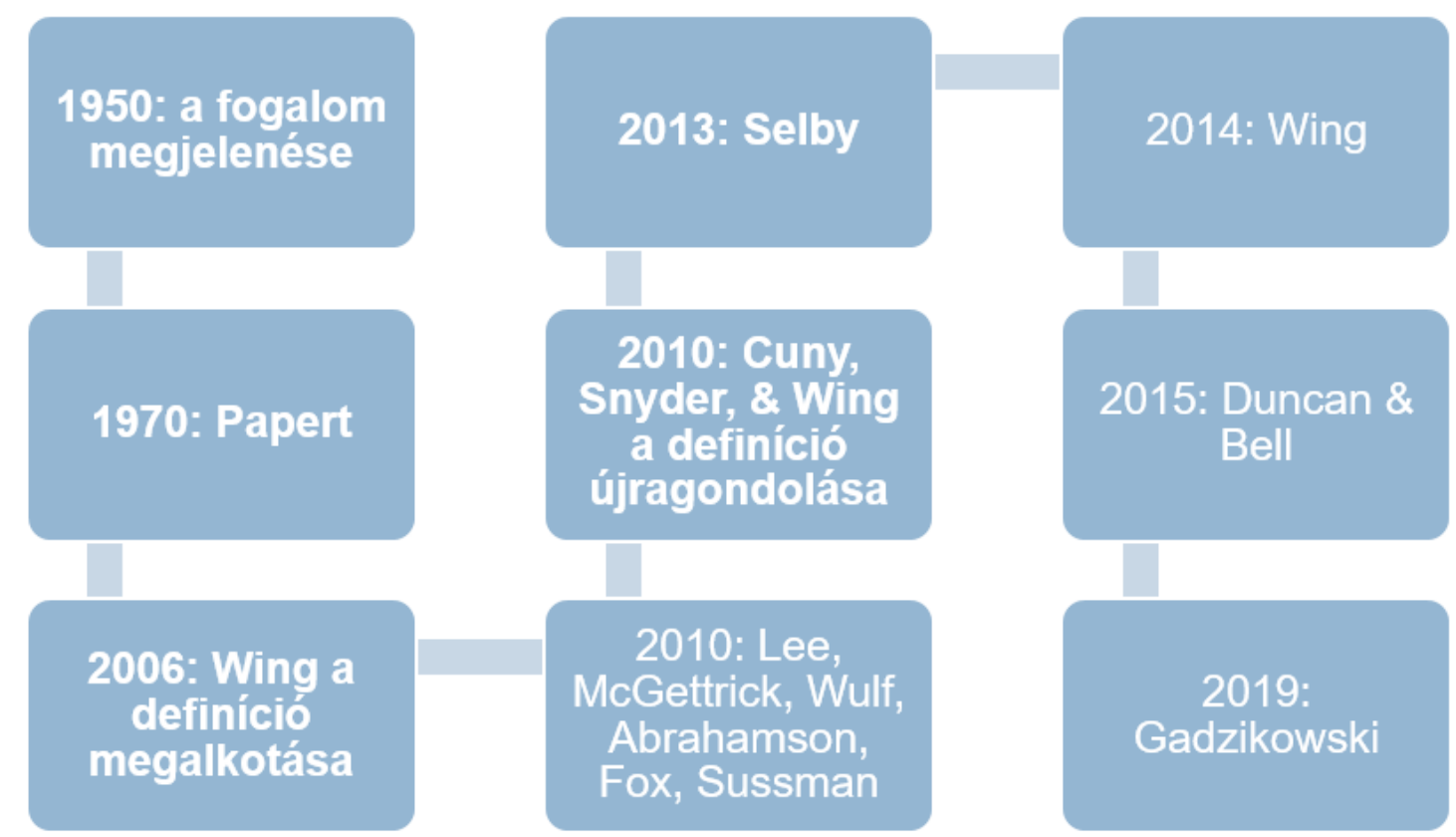

2. ábra: A Computational Thinking (CT) fogalom „evolúciójának" legfontosabb állomásai (Forrás: a szerző saját ábrája)

Az 1950-es években jelent meg a CT fogalma a számítógép-tudomány jellemzöjeként. Az 1970-es években Seymour Papert, az MIT professzora, a Logo programozási nyelvet a CT-n keresztül mutatta be a diákoknak.

$2 \quad$ Stephanie Carretero, Riina Vuorikari, Yves Punie. "DigComp 2.1: The Digital Competence Framework for Citizens with eight proficiency levels and examples of use." Luxembourg, Sweden: Joint Research Centre of the European Commission, 2017. http://publications.jrc.ec.europa.eu/repository/bitstream/JRC106281/web-digcomp2.1pdf___ (online).pdf 
A Computational Thinking fogalmát Jeanette Wing a 2006-ban megjelent cikkében határozta meg. Véleménye szerint az informatikai gondolkodás magába foglalja a problémák megoldását, a rendszerek tervezését, és az emberi viselkedés megértését, a számítástudomány alapelvei alapján. ${ }^{3}$

Jeanette Wing meg van arról győződve, hogy a XXI. század közepére az írás, az olvasás és a számtan mellett az informatikai gondolkodás megjelenik, mint a 4. alapvető készség.

Jeanette Wing a CT fogalmát 2010-ben újragondolta, és megalkotta az egyik leggyakrabban idézett meghatározást, miszerint az informatikai gondolkodás a problémák megoldására irányuló gondolkodási folyamat, amely segíti, hatékonyabbá teszi az információ feldolgozásának müveletét. ${ }^{4}$

Cynthia C. Selby értelmezésében az informatikai gondolkodáshoz szükséges képességek: absztrakt fogalmakban gondolkodás, részekre bontás a gondolkodás során, algoritmikus gondolkodás, értékelésben való gondolkodás és általánositás képessége a gondolkodás során. ${ }^{5}$

Gerald Jay Sussman professzor meghatározása alapján az informatikai gondolkodás szigorú elemzést és eljárásokat foglalmagában egy meghatározott feladat hatékony végrehajtásához. ${ }^{6}$

Ann Gadzikowski kutatási alapján az informatikai gondolkodás négy készségkategória kombinációja: mintafelismerés, algoritmusok létrehozása és használata, elemi részekre bontás, az absztrakciók megértése. ${ }^{7}$ A mintafelismerés során az óvodások elsajátítják az alakzatok formák és színek szerint történő szétválogatását. Az algoritmus szó valamilyen müveletsort, tevékenységet jelent, amellyel egy adott probléma megoldását adjuk meg. Olyan egyszerü feladatok megoldására kell itt gondolni, mint pl. egy gomb felvarrásának vagy egy pite sütésének lépései. Az elemi részekre történő bontással pl. a matematikában találkozhatunk, amikor egy háromjegyü számot helyiérték szerint fel kell bontanunk százasokra, tízesekre és egyesekre. Az absztrakciók megértése magában foglalja az általánositások

3 Jeannette M. Wing. "Computational Thinking," Communications of the Association for Computing Machinery Viewpoint, March 2006, pp. 33-35.

http://www.cs.cmu.edu/ ./15110-s13/Wingo6-ct.pdf

$4 \quad$ Jan Cuny, Larry Snyder, and Jeannette M. Wing. "Demystifying Computational Thinking for Non-Computer Scientists" work in progress, 2010.

$5 \quad$ Pluhár, Zsuzsa és Torma, Hajnalka és Törley, Gábor. "Hallgatói teljesitményértékelés az algoritmikus gondolkodás tükrében." In: InfoDidact 2018. Webdidaktika Alapitvány, Budapest, pp. 1-10., 2019. http://real.mtak.hu/g2129/

$6 \quad$ National Research Council. "Report of a Workshop on the Scope and Nature of Computational Thinking." Washington, DC: The National Academies Press, 2010 https://doi.org/10.17226/12840

7 Ann Gadzikowski. "Planting the Seeds of Computational Thinking in Early Childhood.",2019. http://anngadzikowski.com/planting-the-seeds-of-computational-thinking-in-earlychildhood/ 
készitését, a következtetések levonását és más problémamegoldást célzó gondolkodási folyamatok tervezését.

Összegzésként kijelenthetjük, hogy az informatikai gondolkodás az 1950-es években kialakult felfogáshoz képest jelentős tartalombővülésen ment keresztül az elmúlt évtizedekben, hiszen a számítástudományi gyökerektől elindulva napjainkra egy átfogóbb, az egyén információ feldolgozása közben végbemenő kognitiv és metakognitiv folyamatokra fókuszáló, összetett fogalmat értünk alatta. ${ }^{8}$ A CT tehát azonban a programozással, hiszen ez egy funkcionális gondolkodási alap(készség), amelyben az egyén gondolkodásmódja legyen az elötérben, nem pedig az, ahogyan a gépek gondolkodnak.

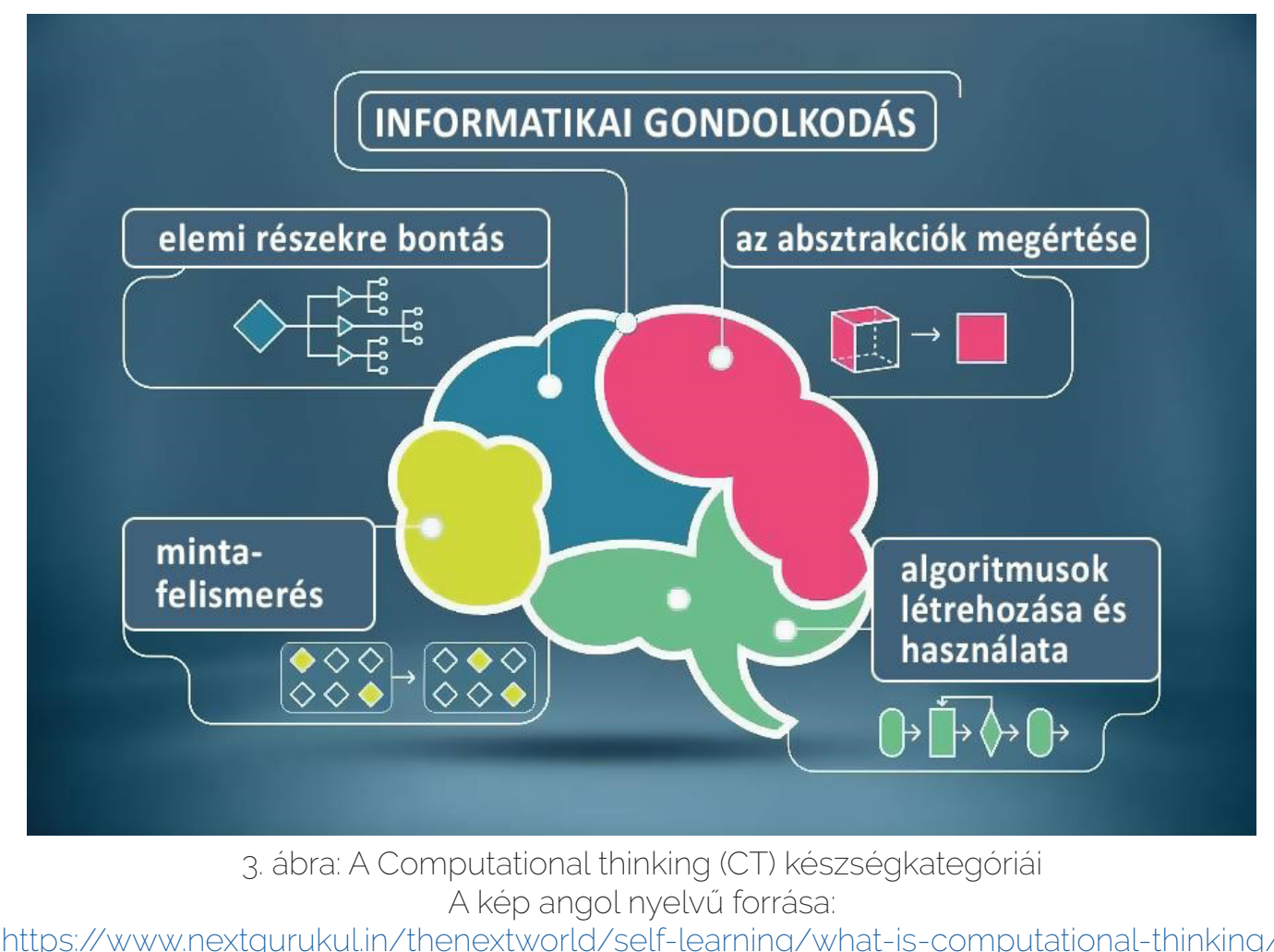

Az informatikai gondolkodás alatt problémák elemeiegységekre történő felbontását értjük, a minták megfigyelését és tendenciák felismerését, a problémamegoldás lépéseinek meghatározását, valamint az absztrakciót, azaz a részletekröl történő elvonatkoztatást, a releváns információkra koncentrálást. E fogalom tehát ötvözi és kiegésziti a matematikai és mérnöki gondolkodást, tartalmazva azon mentális eszközöket, amelyekaszámitógép-tudományterületén használatosszakkifejezések széles skáláját tükrözik. ${ }^{9}$

\footnotetext{
8 Romero, M., Lepage, A. \& Lille, B. "Computational thinking development through creative programming in higher education.", 2017. https://doi.org/10.1186/s41239-017-0080-z Pluhár Zsuzsa. "Az informatikai gondolkodás és a hód." InfoDidac2016 Módszertani konferencia, 2016. https://people.inf.elte.hu/szlavi/InfoDidact16/Manuscripts/PZs_Hod.pdf
} 
A Computational Thinking (CT) tehát ernyőfogalomként hatja át a STEM egyes területeit, hiszen részei többek között az algoritmikus gondolkodás, a problémamegoldás, a programozás oktatása és a szimulációs játékok alkalmazása, szoros kapcsolatot mutatva az információs müveltséggel és a digitális kompetenciával.

\section{A Computational Thinking fogalmának megjelenése a DigComp 2.1-ben}

Napjainkban a digitális kompetencia nemcsak az IKT-hoz való hozzáférést és használatát jelenti, hanem magában foglalja a szükséges ismeretek, készségek és attitüdök birtoklását is.

A 2013-ban megjelent DigComp 1.0 (DIGCOMP: A Framework for Developing and Understanding Digital Competence in Europe) öt kompetenciaterületet jelölt meg: információ, kommunikáció, tartalomkészités, biztonság, problémamegoldás. ${ }^{10}$

A tanulmányban beazonositásra kerültek a digitális állampolgárság komponensei is, amelyet 21 kompetenciaelemre bontottak.

A DigComp 2.0 (DigComp 2.0: The Digital Competence Framework for Citizens. Update Phase 1: the Conceptual Reference Model) az első keretrendszert további elemekkel bővitette, illetve kitért a kompetenciaelemekben való jártasság szintjeire is. ${ }^{11}$

A cikk irásakor a legfrissebb, 2017-ben megjelent DigComp 2.1 (DigComp 2.1: The Digital Competence Framework for Citizens with eight proficiency levels and examples of use) nyolc jártassági szintet és példát mutat be a tanulás és a foglalkoztatás területein.12

Az European Commission weboldalán megtalálható az Európai Unió saját definíciója a Computational Thinking-röl, miszerint: az informatikai gondolkodás egy „számítógépes tudósként" való gondolkodás rövidítése, vagyis a számítógépes

$10 \quad$ Ferrari, Anusca. "DIGCOMP: A Framework for Developing and Understanding Digital Competence in Europe." Luxembourg, Sweden: Joint Research Centre of the European Commission, 2013. http://publications.jrc.ec.europa.eu/repository/bitstream/JRC83167/lbna-26035-enn.pdf

11 Riina Vuorikari, Yves Punie, Stephanie Carretero, Lieve Van den Brande. "DigComp 2.o: The Digital Competence Framework for Citizens. Update Phase 1: the Conceptual Reference Model." Luxembourg, Sweden: Joint Research Centre of the European Commission, 2016. http://publications.jrc.ec.europa.eu/repository/bitstream/JRC101254/jrc101254_digcomp\%20 2.0\%20the\%20digital\%20competence\%20framework\%20for\%20citizens.\%20update\%20 phase\%201.pdf

12 Stephanie Carretero, Riina Vuorikari, Yves Punie. "DigComp 2.1: The Digital Competence Framework for Citizens with eight proficiency levels and examples of use." Luxembourg. Sweden: Joint Research Centre of the European Commission, 2017. http://publications.jrc.ec.europa.eu/repository/bitstream/JRC106281/web-digcomp2.1pdf. (online).pdf 
Az informatikai gondolkodás (computational thinking) fogalmi keretei

tudomány fogalmának használata a problémák megfogalmazásához és megoldásához."13

\section{A kutatás folytatása}

E munka egy előkészitő szakaszt képez a további elemzésekhez, amelyben a hazai helyzetet vizsgálnám meg, olyan tekintetben, hogy az oktatásirányítási dokumentumokban (MDOS, 2016; NAT 2018) hogyan jelenik meg e fogalom, valamint annak elemei.

A kutatásom következő fázisában egy attitüdkutatásra kerül sor, amely során az informatikai gondolkodással kapcsolatos vélekedéseket vizsgálnám meg, kombinált paradigma módszerével (Sántha, 2014) a pedagógusképzésben, egy saját fejlesztésü méröeszközzel, kérdőiv, majd interjú formájában.

\section{Irodalom}

Ann Gadzikowski. "Planting the Seeds of Computational Thinking in Early Childhood.",2019.

http://anngadzikowski.com/planting-the-seeds-of-computational-thinking-inearly-childhood/

Digital Economy and Society Index 2018 - Magyarország.

http://europa.eu/rapid/press-release_MEMO-18-3737_en.htm

European Commission. https://ec.europa.eu/jrc/en/computational-thinking

Ferrari, Anusca. "DIGCOMP: A Framework for Developing and Understanding Digital Competence in Europe." Luxembourg, Sweden: Joint Research Centre of the European Commission, 2013. http://publications.jrc.ec.europa.eu/repository/ bitstream/JRC83167/lb-na-26035-enn.pdf

Jan Cuny, Larry Snyder, and Jeannette M. Wing. "Demystifying Computational Thinking for Non-Computer Scientists" work in progress, 2010.

Jeannette M. Wing. "Research Notebook: Computational Thinking - What and Why? The Link." Pittsburgh, PA: Carneige Mellon, 2011.

https://www.cs.cmu.edu/\%7ECompThink/resources/TheLinkWing.pdf

Jeannette M. Wing. "Computational Thinking," Communications of the Association for Computing Machinery Viewpoint, March 2006, pp. 33-35.

http://www.cs.cmu.edu/ ./15110-s13/Wingo6-ct.pdf

Kampylis, P., Punie, Y. "The Computational Thinking Study." EU Science Hub, 2016. https://ec.europa.eu/jrc/en/computational-thinking

13 Kampylis, P., Punie, Y. "The Computational Thinking Study." EU Science Hub, 2016. https://ec.europa.eu/irc/en/computational-thinking 
National Research Council. "Report of a Workshop on the Scope and Nature of Computational Thinking." Washington, DC: The National Academies Press, 2010. https://doi.org/10.17226/12840

Pluhár Zsuzsa. "Az informatikai gondolkodás és a hód." InfoDidac2016 Módszertani konferencia, 2016.

https://people.inf.elte.hu/szlavi/InfoDidact16/Manuscripts/PZs_Hod.pdf

Pluhár, Zsuzsa és Torma, Hajnalka és Törley, Gábor. "Hallgatói teljesitményértékelés az algoritmikus gondolkodás tükrében." In: InfoDidact 2018. Webdidaktika Alapitvány, Budapest, pp. 1-10., 2019. http://real.mtak.hu/92129/

Racsko Réka. "Digitális átállás az oktatásban." Gondolat Kiadó, Veszprém. Iskolakultúra-könyvek 52., 2017.

http://misc.bibl.u-szeged.hu/46196/1/iskolakultura_konyvek_052.pdf

Riina Vuorikari, Yves Punie, Stephanie Carretero, Lieve Van den Brande. "DigComp 2.0: The Digital Competence Framework for Citizens. Update Phase 1: the Conceptual Reference Model." Luxembourg, Sweden: Joint Research Centre of the European Commission, 2016.

http://publications.jrc.ec.europa.eu/repository/bitstream/JRC101254/jrc101254_ digcomp $\% 202.0 \% 20$ the $\% 20$ digital\%20competence $\% 20$ framework $\% 20$ for $\% 20$ citizens.\%20update\%20phase\%201.pdf

Romero, M., Lepage, A. \& Lille, B. "Computational thinking development through creative programming in higher education.", 2017.

https://doi.org/10.1186/s41239-017-0080-z

Selby C. "Computational Thinking: The Developing Defenition." Submitted for ItiCSE Conference 2013. http://people.cs.vt.edu/\%7Ekafura/CS6604/Papers/CTDeveloping-Definition.pdf

Stephanie Carretero, Riina Vuorikari, Yves Punie. "DigComp 2.1: The Digital Competence Framework for Citizens with eight proficiency levels and examples of use." Luxembourg, Sweden: Joint Research Centre of the European Commission, 2017.

http://publications.jrc.ec.europa.eu/repository/bitstream/JRC106281/webdigcomp2.1pdf_(online).pdf

Szegedi Eszter. "Miért került világszerte fókuszba a STEM területek oktatása?" pp. 9-14., 2014. http://tka.hu/docs/palyazatok/belestem.pdf 